\title{
Socioeconomic and cultural features of consensual unions in Brazil
}

\begin{abstract}
Maira Covre-Sussai*
Consensual unions are a well-known practice among the lower social strata in Latin America. However, this type of union is increasing in the region, among higher educated groups and in countries where they were never widespread, such as in Brazil. This study uses couples' data from the demographic census available at IPUMS $(N=193,689)$ to identify the socioeconomic and cultural features of consensual unions in Brazil. The effects of women's education, couple's income, children, and religion on nuptial behavior are analyzed. Utilizing logistic multilevel analysis, special attention is paid to the effect of differences in the cultural environment of states in the five major regions in which these unions occur. Results indicate that socioeconomic factors affect the incidence of consensual unions in Brazil. Consensual unions are more common among lower income couples and less educated women, but are also found among the upper classes. Cultural diversity between Brazilian states is also reflected in nuptial behavior. Significant variance at the state level is partially explained by the ethnic composition of each state.
\end{abstract}

Keywords: Consensual unions. Cultural differences. Couple’s income. Religion. Children. Multilevel analysis.

\footnotetext{
* Instituto de Ciências Sociais, Departamento de Sociologia, Núcleo de Estudos sobre Desigualdades Contemporâneas e Relações de Gênero (Nuderg), Universidade Estadual do Rio de Janeiro (Uerj), Rio de Janeiro-RJ, Brazil (mairacovre@ gmail.com).
} 


\section{Introduction}

Family patterns have changed noticeably in Western countries since the 1960 s. With an increasing incidence of divorce and the social acceptance of consensual unions, ${ }^{1}$ marriage is no longer considered as the only way to establish a family. Brazil is following Western trends, showing increased rates of divorce and consensual unions. According to the Brazilian Census Bureau (IBGE), the divorce rate in Brazil has increased by more than 500 percent since the 1960s, while the proportion of Brazilian couples cohabiting out of wedlock rose from only 6.4 percent in 1960 to 36.4 percent in 2010 (IBGE, 2010). These changes in nuptiality patterns, associated with the postponement of marriage and decreases in fertility are interpreted by sociologists and demographers as resulting not only from socioeconomic development, but also from shifts in values and beliefs (LESTHAEGHE; SURKYN, 1988).

Formal and informal marriages have historically coexisted in several Latin American countries (CASTRO-MARTIN, 2002; DE VOS, 1987, 1998; ESTEVE; LESTHAEGUE; LOPEZ-GAY, 2012). However, consensual or "traditional" unions practiced in this region over time have a somewhat different meaning from those observed in most developed countries. Traditionally, consensual unions in Latin America have been prevalent in rural areas, as well as among the lower and less educated social classes (ARRIAGADA, 2002; JELIN, 2007). However, there are indicators that another form of consensual union is increasing in many areas of the region, among younger and higher educated cohorts (COVRE-SUSSAI et al. 2013, 2015; ESTEVE; LESTHAEGUE; LOPEZ-GAY, 2012; PARRADO; TIENDA, 1997; VIGNOLI-RODRÍGUEZ, 2005). These consensual unions are considered 'modern' and can be viewed as similar to the consensual unions practiced by higher educated groups in developed countries.

So far, however, there has been little analysis attempting to disentangle consensual unions in different social strata in Latin America (for three exceptions see COVRE-SUSSAl et al. 2015; PARRADO; TIENDA, 1997; LAPLANTE; STREET, 2009). This study addresses that gap by examining the socioeconomic and cultural features of consensual unions in Brazil, paying special attention to the contextual environment in which these unions occur, inasmuch as this differs considerably among the twenty-six Brazilian states and the Federal District. ${ }^{2}$

Considering that the five major Brazilian regions present a notable level of internal homogeneity, this initial contextual analysis is carried out at the level of these regions instead of states for the sake of parsimony. Accentuated regional and social inequalities as well as cultural differences within Brazil reflect the Latin American reality faithfully. The North and Northeast regions are the poorest: according to 2008 data, between 17.6 and

\footnotetext{
${ }^{1}$ According to the UN Multilingual Demographic Dictionary (2013), the term consensual union refers to a socially recognized stable union. Although the term used in this study follows IPUMS-International definition, which labels couples in study here as living in 'consensual unions', it is important to note that it is not possible to attest the level of social recognition or stability of these unions.

2 Politically, Brazil is divided into twenty-six states and the Federal District (Brasília) which are geographically grouped into five regions (North, Northeast, Southeast, South and Central-West). The states have independent administration, subject only to the Brazilian Constitution, the Civil Code and its own state Constitution. They have autonomy but not sovereignty.
} 
24.9 percent of their population, respectively, was living in extreme poverty (IPEA, 2010). Urbanization in Brazilian states ranges from 97.4 percent (Rio de Janeiro, Southeast) to 60.2 percent (Maranhão, Northeast) and illiteracy rates vary from 16.9 percent in the Northeast to 4.8 percent in the Southeast (IBGE, 2012). Nuptiality patterns also show large differences among Brazilian regions: data from the 2010 census indicate that while 30.6 percent of couples in the Southeast region were cohabiting rather than being married, 52.8 percent of their Northern counterparts were living in out-of-wedlock unions (IBGE, 2013a).

Such diversity makes Brazil an ideal case study for examining the socioeconomic and cultural dimensions of nuptiality behavior in Latin America. Although each Brazilian state has its own colonization history, ethnic and religious composition and economic development stage (ranging from very industrialized to quite rural), all are under the same legislative framework. In addition, the Brazilian census provides rich individual level information to support the study of other factors affecting consensual unions, such as religious orientation and family income.

To the best of our knowledge, this is the first study on nuptiality that focuses on the socioeconomic and cultural features of consensual unions within the context of different Brazilian realities. Considering that union formation is a first step which shapes further decisions in the family, and that the family is a fundamental unit of society, the evidence provided here is central to sociological and demographic studies in general, and especially for those focused on family. Moreover, this research is a relevant source of information for governments and policymakers concerned with the implications of the growing number of informal unions on family organization and on the well-being of family members.

To this end, the present study uses data from the 2010 Brazilian demographic census to examine the socioeconomic and cultural features of consensual unions. Socioeconomic characteristics, such as women's education, number of children, couples' income and religious orientation are taken into consideration, as is the contextual environment in which the unions occur.

In the following sections, the study is positioned within the context of existing theoretical frameworks and previous empirical results found on the theme. Research questions are initially set within the context of the theoretical framework of the Second Demographic Transition (SDT) and of previous research on consensual unions in Brazil and in Latin America. Next, Brazilian regional and state-level differences on nuptial behavior are considered. Subsequently, data, variables and empirical results are presented and discussed.

\section{Consensual unions in Brazil: signs of an SDT?}

According to the theoretical framework of the Second Demographic Transition (SDT), the increasing incidence of consensual unions and childbearing in this type of marital union is an outcome of socioeconomic development and of shifts in the ideational domain towards post-modern values such as secularization and individualization. Socioeconomic 
advantages reduce people's preoccupations with basic material needs, such as education, income, working conditions and health. It makes room for the rise of non-material needs, such as equality, freedom and self-expression, changing people's values in the direction of more egalitarian family relations and forms (LESTHAEGHE, 2010) and documents the spread of the SDT to the point that it now covers most European populations. Also for Europe, it focuses on the relationship between the SDT and the growing heterogeneity in period fertility levels. It is shown that the current positive relationship between SDT and TFR levels is not a violation of the SDT theory, but the outcome of a \"split correlation\" with different sub-narratives concerning the onset of fertility postponement and the degree of subsequent recuperation in two parts of Europe. The second part of the article addresses the issue of whether the SDT has spread or is currently spreading in industrialized Asian countries. Evidence gathered for Japan, South Korea, Hong Kong, Singapore, and Taiwan is presented. That evidence pertains to both the macro-level (national trends in postponement of marriage and parenthood, rise of cohabitation.

Consensual unions are historically common among the lower social classes in Latin American societies. However, since the 1960s, the incidence of consensual unions has increased in the region, mainly in countries where this type of union had historically shown less expressive numbers such as Brazil. Since then, the choice for cohabiting instead of marrying is assumed to be related to both historical roots and post-modernity, depending on the social group under analysis (CASTRO-MARTIN, 2002). In line with the statement by Castro-Martin (2002) that the prevalence of consensual unions in Latin America is also related to post-modernity, Esteve and colleagues have suggested that the "cohabitation boom" in Latin America is driven by changes in the ideational domain in the direction of non-conventional ethics and secularization (ESTEVE; LESTHAEGUE; LOPEZ-GAY, 2012). This line of thought prompts the first research question of this study: To what extent are consensual unions related to secularization in Brazil?

After a transition to democratic government in 1986, noteworthy socioeconomic development was registered in Brazil. Expansion of mass education, coupled with rural to urban migration and rapid urbanization have altered the organization of Brazilian society significantly. Nevertheless, the benefits of economic development have not yet reached the majority of the population and social inequality is another central feature of the country (IBGE, 2012). In this scenario of improving socioeconomic development combined with social inequality it is meaningful to question: To what degree are consensual unions related to social class in Brazil?

In Latin America, the traditional type of consensual unions has usually been a substitute for marriage, and childbearing a normal part of it. However, childbearing in traditional cohabiting unions in Latin America is not a signal of secularization or egalitarian relationships, as observed in consensual unions among higher educated groups in the developed West. The traditional consensual union in Latin America is usually established as a strategy to overcome problems related to poverty, or as a response to single or teenager 
motherhood, and they commonly end up in separation or in marriage (CASTRO-MARTIN, 2002; PARRADO; TIENDA, 1997), even when children are grown up (DE VOS, 1998). As in other Latin American countries, high fertility is a common feature of cohabitating unions in Brazil. Indeed, the total fertility rate is higher for cohabitants than for legally married couples in some regions of the country (LAZO; MORAES, 2004). Consequently, it is pertinent to ask: How does childbearing in cohabitating unions relate to social class?

The SDT framework states that nuptial behavior is related not only to socioeconomic factors, but also to the social acceptability of a given behavior. Extensive cultural diversity found in Brazil suggests the need to understand how couples' dynamics are embedded in distinct socioeconomic and cultural contexts. The cultural variances found in Brazil induce the question: To what extent is the cultural context related to couples' probability of being married on the one hand or of cohabiting on the other?

\section{The Brazilian context of consensual unions}

Similar to most Latin American countries, consensual unions in Brazil have historical roots, although they occurred in lower numbers than in other countries of the region. Brazilian family organization also follows other traits of Latin American history, which was marked by patriarchal and interracial relationships. The family patterns of the native indigenous population, in which marriage did not play a central role, were completely dissimilar to that of the European colonizers. Wife lending, for instance, was a common practice among these pre-Colombian civilizations. During the colonization period, Portuguese colonizers used to constitute 'new families' with indigenous women abroad, partly as a strategy to obtain the help of indigenous groups in exploring the land (RIBEIRO, 1997).

With the advent of slavery, which lasted from the $16^{\text {th }}$ to $19^{\text {th }}$ century, slaves coming from different parts of the African continent were introduced in the country en masse (RIBEIRO, 1997). At that time, marriage was under the control of the Catholic Church and marriage encouraged. However, slave masters restricted legal marriage among slaves, because it made it more difficult to sell married slaves separately (HOLT, 2005). Therefore, in Brazilian colonial society, people from the lower social classes and disadvantaged ethnic groups (indigenous and blacks) commonly constituted their families in out-of-wedlock relationships.

Conversely, marriage was always highly valued by the upper classes in Brazil, and children born outside of wedlock unions were considered illegitimate (SAMARA, 1987). Generally, while consensual unions were common among the lower social strata until the middle of the $20^{\text {th }}$ century, the institutions of marriage and the family among the upper classes were based on hierarchic, authoritarian and patriarchal relationships, under the strong influence of Catholic-based morality (FREYRE, 2000). Moreover, many demographers and historians point to a notable variance in terms of family compositions and roles among different social strata and regions of the country (ALMEIDA, 1987; CORRÊA, 1993; SAMARA; COSTA, 1997; SAMARA, 
1987; SOUZA; BOTELHO, 2001). It is now well accepted in the Brazilian social sciences that the influence of the Catholic Church on family life, the patriarchal model of family and gender and ethnic relations inside the family, all vary considerably across Brazilian regions and social classes (SAMARA, 2010; SOUZA; BOTELHO, 2001).

Despite its historical roots, the incidence of consensual unions in Brazil differs from the Latin American rates found in Central American or the Caribbean countries. In Panama, 62 percent of women in the age group 25 to 29 years old were cohabiting rather than married in 1970, while the figure for the same group and year in Brazil was only 7.5 percent (IPUMS data, own calculations, Minnesota Population Center, 2011). However, during the 1970s, the incidence of consensual unions started to increase in Brazil, reaching 36.4 percent of all unions in 2010 (IBGE, 2010).

\section{Long-term demographic developments}

Brazil boasts a unified legal framework, language and traditions that coexist with a plurality of subcultures and regions in different stages of socioeconomic development. The country's extensive diversity suggests the need to understand how couples' dynamics are embedded in these dissimilar environments. These contexts can be illustrated along the lines of the country's five major regions, although attentive observers can find considerable variance in terms of cultural environment and socioeconomic development within these regions as well.

The origins of 'cultural differences' in Brazil were ably summarized by anthropologist Darcy Ribeiro (1997). He suggested that the country's vast territory $\left(8,547,403.5 \mathrm{~km}^{2}\right)$, its substantial and growing population (more than 190 million in 2010), formed by different cultures (mainly native indigenous, African and European, but with participation of Asiatic, Arabian and others), and its extensive variety of climate, terrain and vegetation, have determined the division of Brazil into different subcultures, distributed throughout the five regions (RIBEIRO, 1997).

According to 2011 data provided by IBGE (2013a), the North and Northeast regions have higher proportions of mixed race populations (pardos: mainly the mixture of native indigenous, European and African descendants), with 68 and 60 percent of the population, respectively, self-declared as pardo. In the Northeast, the family model described by Freyre (2000 [1933]) as patriarchal and hierarchic was most visible. According to Ribeiro (1997), the sub-cultures of both the North and Northeast are characterized by a patriarchal social system highlighting group norms and group loyalty (RIBEIRO, 1997).

Until the second half of the $19^{\text {th }}$ century, the population of the Southeastern and Southern regions was formed by the union of Portuguese colonizer with indigenous people and some African slaves. During the colonial period, expeditions embarked from the city of São Paulo in order to explore the mineral riches found in the interior and to occupy the region beyond the Tordesillas line by Brazilians. During this period, while husbands went to 
the countryside, wives took care of children and the household unit as a whole. This system fostered less hierarchic family relationships than the ones observed in the North of the country (ALMEIDA, 1987; CORRÊA, 1993; SAMARA; COSTA, 1997; SAMARA, 1987; SOUZA; BOTELHO, 2001). Today, the descendants of these early settlers in the Southeast and South share their regions with social groups composed of descendants from the large European immigration of the $19^{\text {th }}$ and $20^{\text {th }}$ centuries, especially Italians and Germans. These migrants reinforced the European model of the family in those two regions, with a strong emphasis on marriage. These historical roots also explain the contemporary majority of self-declared whites in the South and Southeast (78 and 56 percent, respectively - IBGE, 2013a).

The last sub-culture identified by Ribeiro (1997) includes people from the inland part of the Northeast and, particularly, from the Central-West area, which presents more rural characteristics. The Central-West region contains the most balanced division of ethnicities in Brazil with 43 percent of whites, 48 percent of pardos, 7.6 percent of African descent and about 1 percent of indigenous and Asiatic descent (IBGE, 2013a). The development of this region started later compared to the coastline and was accelerated, in part, by the transfer of the country's administrative capital from Rio de Janeiro to Brasília (Federal District) in 1960. Although this region had remained relatively unsettled up to that time, the creation of a new capital city (Brasília was built between 1956 and 1960) legitimated its autonomy and social status differences, although its rural area still holds a small population in subsistence agriculture (RIBEIRO, 1997).

The current socioeconomic development of Brazilian regions is related (among other factors) to different processes of occupation and industrialization. Industrialization and urbanization started earlier and increased faster in the Southern regions than in the Northern ones (GUIMARÃES NETO, 1998). With the social investments realized in recent years, the gap in socioeconomic development among Brazilian regions has been reduced, but is still evident (IBGE, 2012, p. 168). The North and Northeast regions are the poorest and least developed in the country. These are regions where between 24.9 and 17.6 percent of the population were living in extreme poverty, in comparison to $11.6,6.9$ and 5.5 percent of the population in the Central-West, Southeast and South, respectively (IPEA, 2010). The North and Northeast regions also present the lowest Human Development Index ( 0.75 and 0.79 , respectively) contrasted to 0.85 in the South and 0.84 in the Southeast and Central-West (BCB, 2009).

Significant variations are also found in the demographic conditions of different Brazilian regions. Porter et al. (2010) demonstrated that the fertility transition occurred with a different tempo and quantum in the five regions. According to these authors, the Southeast and South presented the earliest transition; this, associated to later and less universal marriage shows a "European" pattern that is completely different from the transition presented in the North and Northeast. In addition, Camarano and Carneiro (1998) concluded that it is impossible to identify a unitary pattern of family formation indicators (i.e. adolescent pregnancy, age at first birth, fertility control, among others) across Brazilian regions. 
Such differences among Brazilian regions are reflected in nuptiality trends. Graph 1 presents the longitudinal marriage and divorce rates for Brazil and its five regions. The general trend shows almost constant marriage rates since the $1990 \mathrm{~s}$, but growing divorce rates since the 1980s. In addition, the divorce rates for the Southeast, South and CentralWest regions were clearly higher and increased more sharply than the figures for the North and Northeast. Lower marriage and divorce rates can be explained by the fact that these two latter regions present higher percentages of couples living in consensual unions. Graph 2 demonstrates the proportion of married and cohabiting couples in Brazil and its five regions in 2010.

GRAPH 1

Marriage and divorce rates by Brazilian regions - 1980-2014

(i) Evolution of marriage rate

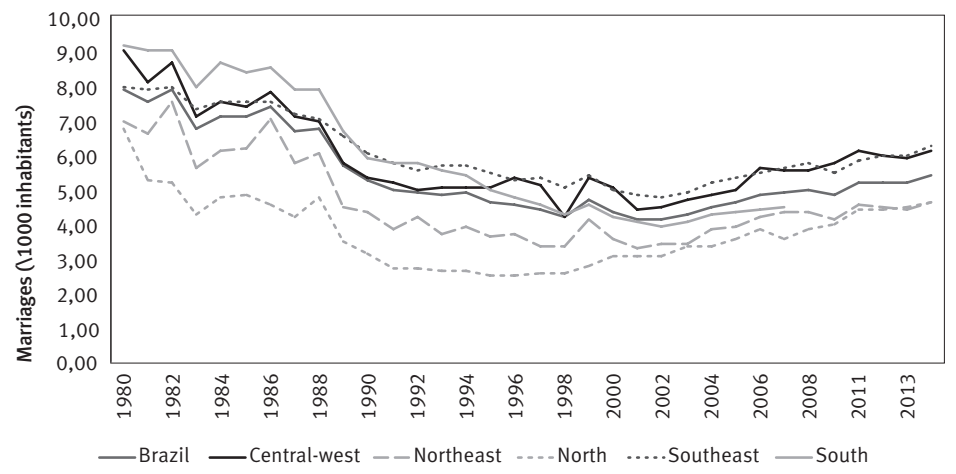

(ii) Evolution of divorce rate

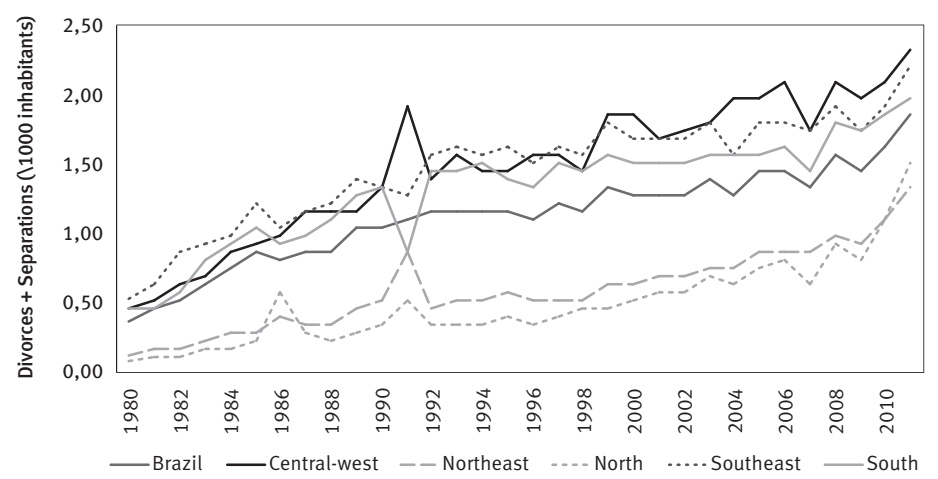

Source IBGE. Estatísticas do Registro Civil, 1980 to 2013.

While 33 and 31 percent of couples living in states of the Southeast and South regions, respectively, are cohabitating rather than married, the figures for the couples in the Northeast and North are 42 and 53 percent, respectively. Figures for the states in these two latter regions are comparable to those for consensual unions in Caribbean and Central American countries, such as Panama, where consensual unions made up 53 percent of the 
total in the 2000 census. The figures for the Southern regions are closer to those of countries in the Southern Cone, such as Uruguay, which had 26 percent of couples in consensual unions in1995 (census data, IPUMS, own calculations).

GRAPH 2

Percentage of couples living in consensual unions by state and region Brazil - 2010

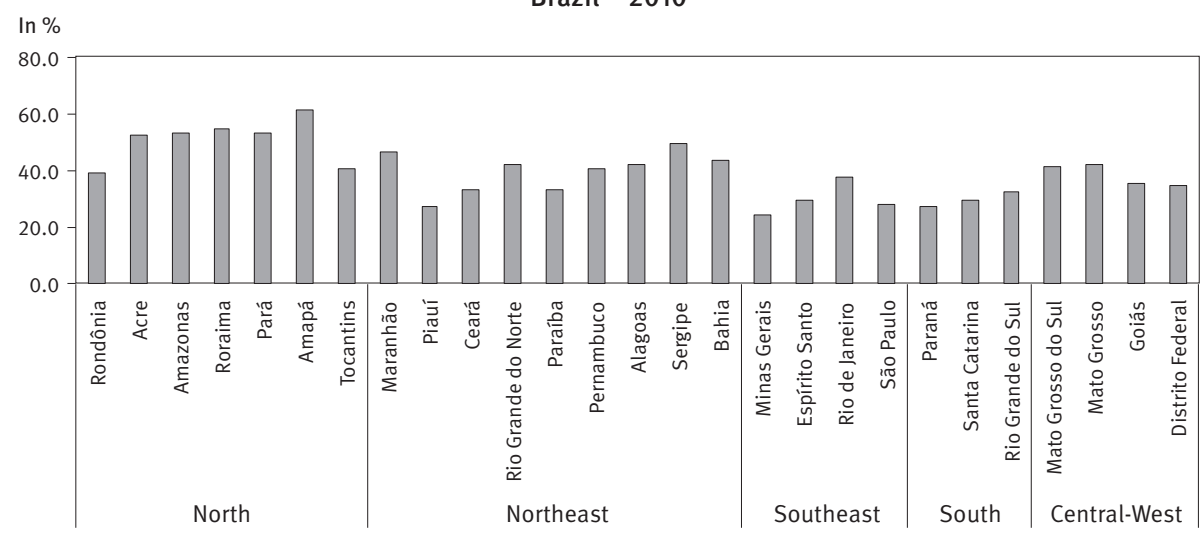

Source: IBGE. Censo Demográfico 2010.

Accordingly, it is expected that significant variance will be found at the state-level, but also that this variance is mainly related to contextual differences, such as socioeconomic development, urbanization and ethnic composition.

\section{The influence of religion}

Although the Catholic Church has lost much of its previous authority, Brazil has not become a completely secular country. However, religious diversity has grown substantially in recent decades. The main trend revealed by the 2010 census is a great increase in the variety of religions (about 141 different religions and sects) concentrated predominantly in the urban areas of the country. Nevertheless, the majority of Brazilians remain Roman Catholic, despite the relative losses. The second highest proportion of religious people is made up of Evangelicals and Protestants, who saw a noticeable expansion, mainly among Pentecostals. However, in 2010, the proportion of people without religion also increased by 3 percent in comparison to 1990, now amounting to 8 percent of the total (ALVES, 2012).

Meanwhile, the proportion of religious marriages (whether only religious or combined with a civil one) has declined substantially over time. Religious marriages were predominant in Brazil until the end of the $19^{\text {th }}$ century, when they constituted the only official form of marriage. When Brazil became a Republic in 1890, civil marriages became the only ones with juridical validity, but people were allowed to choose between civil or civil with religious marriage. The combination of civil and religious marriage was predominant until the $1980 \mathrm{~s}$ when its incidence started to decline sharply. 
The Brazilian Census Bureau started to differentiate the type of union (civil, religious, civil and religious or consensual union) of couples as of the 1960 census. Graph 3 illustrates the evolution of these unions from 1960 to 2010.

GRAPH 3

Percentage of couples per type of marital union

Brazil - 1960-2010

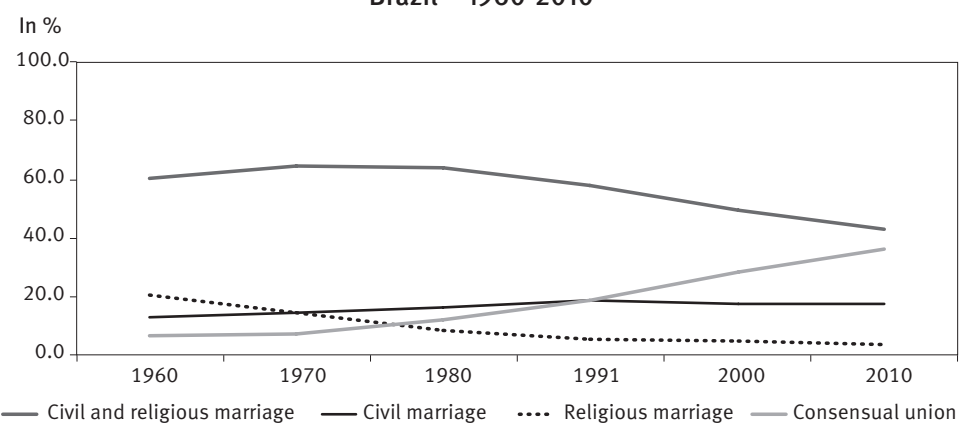

Source: IBGE (2013a).

Graph 3 shows a practically constant level of civil marriages, but a sharp increase in consensual unions together with almost constant decreases of civil and religious and only religious marriages since the 1980 s.

It is interesting to note that the proportion of consensual unions and civil and religious marriage is almost equal in 2010. These trends can be seen as a sign of secularization in Brazil, which is one of the ingredients of the SDT. However, considering the continuing popularity of several types of religious denominations in the country, and that marriage is highly encouraged within them, it is expected that couples with a religious denomination are less likely to cohabit rather than getting married, compared to couples without a religious denomination.

\section{Multi-level research and findings}

\section{Data: Brazilian demographic census}

An individual-level dataset from the long questionnaire of the Brazilian 2010 demographic census available at IPUMS (MINNESOTA POPULATION CENTER, 2011) is used. The long questionnaire contains general and more specific information about the characteristics of dwellings, families, and each of the people in the dwellings. It contains information about the individuals' current marital status (civil marriage, religious marriage, both or consensual union), as well as information on socioeconomic position, children and the religious orientation of both partners/spouses.

Considering that second or higher order unions are very different from first unions (BROWN, 2000), it would have been interesting to differentiate them in the analysis. However, the information required for such an investigation is not available in the Brazilian census and this analysis refers only to the current conjugal status of the couple. 
The total sample is composed of 3,875,520 couples, from all age groups, formally married or living in a consensual union. From this sample, a file composed of 1,937,760 couples was created. The multilevel logistic analysis was conducted using the software SAS (PROC GLIMMIX), which was able to handle the sample size. Considering that a 'couple's data' was created, the household weight (WTHH) provided by IPUMS was applied. ${ }^{3}$

\section{Variables}

The variables used in this study were constructed as follows: the dependent variable indicating the type of union, consensual union or marriage, was computed from the census question related to the individual's civil status, for the current partnership of the woman: consensual union (1) or married (0).

Couples' level predictor variables used are of three types. Couples' religion is categorized as follows: (1) catholics, when both man and woman are self-declared catholics; (2) evangelicals, when both man and woman are self-declared evangelicals, pentecostal evangelicals or protestant; (3) other, when both man and woman declare to be from the same other religious groups, and (4) different religion, when man and woman declare a different religious orientation.

Three categories are created to analyze the presence of children in consensual unions in comparison to marriages: (1) none, when the couple has no child; (2) up to two, when the couple has one or two children and (3) three or more children. In order to categorize couple's income, the measurement scheme proposed by Neri (2008) was used. In this approach, the author considered factors such as social ascension possibilities, quality of life, consumption potential (which is measured by access to goods, services and educational level of the reference person) and the ability to sustain this potential over time (Neri, 2008, p. 24). The variable 'social class' differentiates (1) poor couples, with monthly family income lower than R\$ 768.00; (2) working class couples, with family income between $\mathrm{R} \$ 768.00$ and $R \$ 1,063.00$; (3) middle class couples, with family income between $R \$ 1,064.00$ and $R \$ 4,590.00$, and (4) upper class couples, with family income higher than $R \$ 4,591.00$. In order to assess the conditional association between having children and the likelihood of being married vs. cohabitating, an interaction term between the categorical variables children and social class is included in the model.

Three variables were added as couples-level control variables. The educational level of the woman is classified as (1) less than primary, (2) primary, (3) secondary or (4) university or higher. The birth cohort of the man controls for the cohort of the couple. It ranges from 1940 to 1990. A dummy variable labeled migrant indicates if one or both partners/spouses were not born in the state in which they live.

Although the theoretical arguments were built on the idea of regional differences, states rather than regions are used as a level of analysis. This choice was made for practical and

\footnotetext{
${ }^{3}$ IPUMS project publishes a re-sampled file based on the Demographic Census of Brazil that presents different sample sizes depending on the size of the municipalities, varying from $5 \%$ to $50 \%$.
} 
methodological reasons. First, although there are common features among states in the same region, states represent the Brazilian heterogeneity in a much more accurate way than the regions. Second, the heterogeneity found among Brazilian states can also be observed among states within the same region. Third, the states have independent administrations, subject only to the Brazilian Constitution, the Civil Code and its own state Constitution. Thus, they also have some autonomy, although not sovereignty. In addition, the variance found in the five regions is not enough to include regions as an independent level, nor to guarantee an accurate estimation of a regional effect if it exists. In this sense, the contextual variables measuring the socioeconomic and cultural environments are based on couples' place of residence, namely, the 26 states and the Federal District (which is treated as a state). The state-level urbanization rate, the state-level Human Development Index (HDI), ${ }^{4}$ and the variable called poverty, which designates the percentage of people considered poor in 2010 (PNUD, 2010) are included as indicators of socioeconomic development.

As stated earlier, consensual unions were historically common among the native indigenous and African descendant populations. Traditionally, European descendants, coming from Portugal during the colonization period or later from several European countries, mostly Italy and Germany, tend to follow the old European pattern of marriage, with a low incidence of consensual unions. Based on this reality, the proportion of selfdeclared whites in each state is included in the model as a proxy for cultural environment.

Finally, Greene and Rao (1995) interpret consensual unions in Brazil as a solution for the marriage squeeze in the country. According to them, faced with higher numbers of women in the marriage market, Brazilian men tend to be 'recycled' through multiple unions (a type of longitudinal polygamy). To take this into account, the state-level sex ratio is included as a control variable. Listwise deletion was the method used for handling missing data. In our understanding, the sample size of our data is large enough to avoid generating biased results due to the deletion of missing data.

\section{Method}

Multilevel logistic models are used to analyze the data. With the multilevel approach, it is possible to estimate both the general relationship across all states and the particular relationship in specific ones (DUNCAN, JONES; MOON, 1998), as well as the cultural environment. It allows us to model contextuality (micro and macro relations) and complex structures (couples nested in states). This provides several advantages. For instance, if we focused exclusively on the couples' level, the context of the different regional cultures would be ignored. If we focused only on the aggregate level, we would fail to capture couples' dynamics.

\footnotetext{
${ }^{4}$ It is obtained by the mean of three sub-indexes relating to Longevity (HDI-longevity), Education (HDI-Education) and Income (HDI-income). Source: PNUD (2010).
} 
There are statistical and conceptual problems in analyzing variables from different levels at one single level (HOX, 2002). The first statistical problem occurs when data are aggregated. In our study, if we combine different information about couples into fewer values for state-level units, we would lose both information and statistical power. In contrast, if we try to 'disaggregate' state level information into couples' level data, statistical tests will treat these values as independent information, with much larger number of couples' level observations than we really have in the data. The use of this "larger number of disaggregated cases for the sample size leads to significance tests that reject the null-hypothesis far more often than the nominal alpha level suggests" (HOX, 2002, p. 3). As a consequence, we would end up with spurious 'significant' results (HOX, 2002).

The main conceptual problem of analyzing variables from different levels at the single level is the risk of committing the "fallacy of the wrong level" (HOX, 2002, p. 3). These misconceptions would consist, for example, of analyzing the data at the states' level, and formulating conclusions at the couples' level (known as ecological fallacy). This conceptual problem could also occur the other way around, by interpreting state level results based on couples' level information (known as atomistic fallacy). The last conceptual problem to be aware of is the called 'Simpson's Paradox'. "Simpson's paradox refers to the problem that completely erroneous conclusions may be drawn if grouped data, drawn from heterogeneous populations, are collapsed and analyzed as if they came from a single homogeneous population" (HOX, 2002, p. 4).

Using multilevel procedures, it is also possible to avoid the underestimation of problems caused by contextual variation. The residual variance is partitioned into between-states and within-states variance. There is a couples-level model that represents the within-state equation, and a contextual macro-model, in which the parameters of the within-state model are the responses in the overall, between-states model. This simultaneous specification allocates for the quantitative division of the individual from the contextual (DUNCAN, JONES; MOON, 1998), and the micro-model from the macro-model.

The question regarding the regional effects on couples' nuptial behavior is whether the states' variation will continue to be significant when the other contextual variables are included in the overall model. For instance, if the states' variance is related to poverty or socioeconomic differences, it will disappear (or decrease significantly) when the states' level of poverty or the HDI is introduced into the model. If, on the other hand, the statelevel variation on consensual unions probability is associated to the cultural background measured by the ethnicity composition, it will be reduced when the proportion of whites in each state is included in the model.

\section{Results}

In this study, we use the type of marital union ( 0 =married, 1 cohabiting) as the explanatory variable at the couples' level, with children, social class and couples' religious orientation as couples' level explanatory variables. Urbanization rate, HDI, level of poverty, 
and proportion of whites are used as state-level explanatory variables. ${ }^{5}$ We also control for women's education, migration, the birth cohort of the man and the state-level sex ratio.

The link function used to analyse this data is the logit function: $\operatorname{logit}(\mathrm{p})=\ln (\mathrm{p} /(\mathrm{l}-\mathrm{p}))$, which can be concisely written as:

$\operatorname{Logit}\left(\mathrm{p}\left(\right.\right.$ Cohabit $\left.\left._{i}\right)\right)=\beta_{0}+\beta_{1}$ children $_{i j}+\beta_{2}$ class $_{i j}+\beta_{3}$ religion $_{i j}+\beta_{4}$ education $_{i j}+\beta_{5}$ cohort $_{i j}+$ $\beta_{6}$ migrant $_{i j}+\beta_{7}$ urbrate $_{j}+\beta_{8}$ HDI $_{j}+\beta_{9}$ poverty $_{j}+\beta_{10}$ whites $_{j}+\beta_{11}$ sexratio $_{j}+\mathrm{e}_{i j}+\hat{\mathrm{u}}_{0 j}$ where $i$ is the couple, $j$ is the Brazilian state and $\hat{\mathrm{u}}_{0 j}$ is the states-level differential.

The models were fit stepwise. We started with the random intercept null model with consensual union being the response variable and only a constant term in the model. Subsequently, models with increasing complexity were tested, until we ended up with the full model. The intercept ( $\beta_{0}$ not shown) of the null model is -0.42 . It means that, for the null model, across the country, or for every couple, everywhere, the expected odds $\left(\exp \left(\beta_{0}\right)\right)$ of consensual union in comparison to marriage is 0.65 . In other words, the probability (odds/[1+odds]) of a couple to cohabit in Brazil instead of being married is 0.40 . However, there is significant (at level 0.001 ) evidence that this probability varies throughout the country. The variance of $\mathrm{u}_{0 j}$ between states is estimated as $\hat{\sigma}_{o j}^{2}=0.16$. Accordingly, a multilevel approach is meaningful.

TABLE 1

Models predicting the odds of living in consensual union instead of in marriage Brazil - 2010

\begin{tabular}{|c|c|c|c|c|c|c|c|c|c|}
\hline \multirow{2}{*}{$\begin{array}{c}\text { Couples' level } \\
\text { variables }\end{array}$} & \multicolumn{3}{|c|}{ Model 1} & \multicolumn{3}{|c|}{ Model 2} & \multicolumn{3}{|c|}{ Model 3} \\
\hline & B & $\mathrm{SE}$ & Odds & B & SE & Odds & B & SE & Odds \\
\hline \multicolumn{10}{|l|}{$\begin{array}{l}\text { Children: None } \\
\text { (ref.) }\end{array}$} \\
\hline Children: Up to two & $-0.642^{\star \star \star}$ & $(0.110)$ & 0.526 & -0.506 & $(0.586)$ & 0.603 & $-0.646^{\star \star \star}$ & $(0.112)$ & 0.524 \\
\hline $\begin{array}{l}\text { Children: Three or } \\
\text { more }\end{array}$ & $-0.529^{\star \star \star}$ & (0.110) & 0.589 & -0.276 & $(0.586)$ & 0.759 & $-0.532^{\star \star \star}$ & $(0.112)$ & 0.587 \\
\hline \multicolumn{10}{|l|}{$\begin{array}{l}\text { Social class } \\
\text { (income): Upper } \\
\text { (ref.) }\end{array}$} \\
\hline Social class: Poor & $0.454^{\star \star \star}$ & $(0.026)$ & 1.575 & 0.727 & $(0.611)$ & 2.069 & $0.457^{\star \star \star}$ & $(0.027)$ & 1.579 \\
\hline $\begin{array}{l}\text { Social class: } \\
\text { Working }\end{array}$ & $0.296^{\star \star \star}$ & $(0.026)$ & 1.344 & 0.414 & $(0.630)$ & 1.513 & $0.300^{\star * \star}$ & $(0.027)$ & 1.35 \\
\hline $\begin{array}{l}\text { Social class: } \\
\text { Middle }\end{array}$ & $0.236^{\star \star \star}$ & $(0.024)$ & 1.266 & 0.374 & $(0.614)$ & 1.454 & $0.239^{* * *}$ & $(0.025)$ & 1.27 \\
\hline \multicolumn{10}{|l|}{$\begin{array}{l}\text { Religion: Different } \\
\text { religion (ref.) }\end{array}$} \\
\hline Religion: Catholics & $-0.393^{\star \star \star}$ & $(0.016)$ & 0.675 & $-0.393^{\star \star \star}$ & $(0.016)$ & 0.675 & $-0.396^{\star \star \star}$ & $(0.016)$ & 0.673 \\
\hline $\begin{array}{l}\text { Religion: } \\
\text { Evengelicals }\end{array}$ & $-1.352^{\star \star \star}$ & $(0.021)$ & 0.259 & $-1.352^{\star \star \star}$ & $(0.021)$ & 0.259 & $-1.365^{\star \star \star}$ & $(0.021)$ & 0.255 \\
\hline Religion: Other & $0.101^{\star \star \star}$ & $(0.023)$ & 1.106 & $0.099^{\star \star \star}$ & $(0.023)$ & 1.104 & $0.101^{\star \star \star}$ & $(0.023)$ & 1.106 \\
\hline
\end{tabular}

\section{Women}

Education: University (ref.)

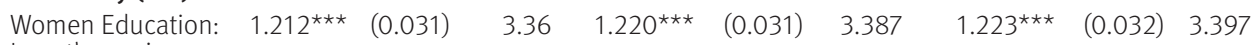
Less than primary

(continue)

\footnotetext{
${ }^{5}$ Considering the cross sectional nature of the data, it is not possible to infer causality. Instead, the results presented in this study represent a rich description of cohabitations in comparison to marriages in Brazil.
} 


\begin{tabular}{|c|c|c|c|c|c|c|c|c|c|}
\hline \multirow{2}{*}{$\begin{array}{l}\text { Couples' level } \\
\text { variables }\end{array}$} & \multicolumn{3}{|c|}{ Model 1} & \multicolumn{3}{|c|}{ Model 2} & \multicolumn{3}{|c|}{ Model 3} \\
\hline & B & SE & Odds & B & SE & Odds & B & SE & Odds \\
\hline $\begin{array}{l}\text { Women Education: } \\
\text { Primary }\end{array}$ & $0.890^{\star \star \star}$ & $(0.024)$ & 2.435 & $0.890^{\star \star \star ~}$ & $(0.024)$ & 2.435 & $0.899^{\star \star \star}$ & $(0.025)$ & 2.457 \\
\hline $\begin{array}{l}\text { Women Education: } \\
\text { Secondary }\end{array}$ & $0.968^{\star \star \star}$ & $(0.024)$ & 2.633 & $0.964^{\star \star \star}$ & $(0.024)$ & 2.622 & $0.977^{\star \star \star}$ & $(0.024)$ & 2.656 \\
\hline \multicolumn{10}{|l|}{$\begin{array}{l}\text { Cohort (man): } \\
1940 \text { (ref.) }\end{array}$} \\
\hline Cohort (man): 1950 & $0.551^{\star \star \star}$ & $(0.020)$ & 1.735 & $0.548^{\star \star \star}$ & $(0.020)$ & 1.73 & $0.555^{\star \star *}$ & $(0.021)$ & 1.742 \\
\hline $\begin{array}{l}\text { Cohort (man): } \\
1960\end{array}$ & $1.047^{\star \star \star}$ & $(0.019)$ & 2.849 & $1.044^{\star \star \star}$ & $(0.019)$ & 2.841 & $1.054^{\star \star \star}$ & $(0.020)$ & 2.869 \\
\hline Cohort (man): 1970 & $1.625^{\star \star \star}$ & (0.019) & 5.078 & $1.619^{\star \star \star}$ & (0.019) & 5.048 & $1.637^{\star \star \star}$ & $(0.020)$ & 5.14 \\
\hline $\begin{array}{l}\text { Cohort (man): } \\
1980\end{array}$ & $2.325^{\star \star \star}$ & $(0.021)$ & 10.23 & $2.314^{\star \star \star}$ & $(0.021)$ & 10.11 & $2.343^{\star \star \star}$ & $(0.022)$ & 10.41 \\
\hline $\begin{array}{l}\text { Cohort (man): } \\
1990\end{array}$ & $3.259^{\star \star \star}$ & $(0.065)$ & 26.02 & $3.250^{\star \star \star}$ & $(0.065)$ & 25.79 & $3.283^{\star \star \star}$ & $(0.064)$ & 26.66 \\
\hline Migrant & $0.273^{\star \star \star}$ & $(0.013)$ & 1.314 & $0.273^{\star \star \star}$ & $(0.013)$ & 1.314 & $0.275^{\star \star \star}$ & $(0.013)$ & 1.317 \\
\hline \multicolumn{10}{|l|}{$\begin{array}{l}\text { No child*Upper } \\
\text { class (ref.) }\end{array}$} \\
\hline $\begin{array}{l}\text { Up to two } \\
\text { children*Poor class }\end{array}$ & & & & $-0.197^{\star \star \star}$ & $(0.611)$ & 0.821 & & & \\
\hline $\begin{array}{l}\text { Three or more } \\
\text { children*Poor class }\end{array}$ & & & & $-0.364^{\star \star \star}$ & $(0.612)$ & 0.695 & & & \\
\hline $\begin{array}{l}\text { Up to two } \\
\text { children*Working } \\
\text { class }\end{array}$ & & & & $-0.005^{\star \star \star}$ & $(0.631)$ & 0.995 & & & \\
\hline $\begin{array}{l}\text { Three or more } \\
\text { children*Working } \\
\text { class }\end{array}$ & & & & $-0.237^{\star \star \star}$ & $(0.631)$ & 0.789 & & & \\
\hline $\begin{array}{l}\text { Up to two } \\
\text { children*Middle } \\
\text { class }\end{array}$ & & & & $-0.119^{\star \star \star}$ & $(0.615)$ & 0.888 & & & \\
\hline $\begin{array}{l}\text { Three or more } \\
\text { children*Middle } \\
\text { class }\end{array}$ & & & & $-0.167^{\star \star \star}$ & $(0.615)$ & 0.846 & & & \\
\hline $\begin{array}{l}\text { Proportion of } \\
\text { Whites (States } \\
\text { level) }\end{array}$ & & & & & & & $-1.005^{\star \star \star}$ & $(0.338)$ & \\
\hline \multicolumn{10}{|l|}{ Random Part } \\
\hline Intercept & $-1.841^{\star \star \star}$ & $(0.135)$ & 0.159 & $-2.018^{\star \star \star}$ & $(0.619)$ & 0.133 & $-1.460^{\star \star \star}$ & $(0.187)$ & 0.232 \\
\hline $\begin{array}{l}\text { Contextual } \\
\text { variance }\end{array}$ & $0.134^{\star \star \star}$ & $(0.037)$ & & $0.135^{\star \star \star}$ & $(0.037)$ & & $0.101^{\star \star \star}$ & $(0.028)$ & \\
\hline
\end{tabular}

Source: IBGE. Censo Demográfico 2010.

$\star \star \star$ p-value $<0.001$

In the next steps, the variables were added stepwise until the full model was reached. The final models are presented in Table 1. The results are presented in terms of logits ( $\beta$ ) and odds ratios, which are obtained by the logits' antilog $(\exp (\beta))$. They are discussed in terms of odds ratios.

Looking at Model 1, it can be seen that the existence of children reduces the odds of cohabiting rather than being married. In comparison with couples without children, the odds of couples with one or two children of living in a cohabiting union instead of being married are $1.90(1 / 0.53)$ times lower, while the odds of couples with three or more children of living in informal unions instead of being married are 1.7 (1/0.59) times 
lower. Considering different social classes, it was found that the odds of cohabitating instead of being married decreases as social class increases. In comparison to the upper classes, the odds of cohabiting rather than being married for the poor are 1.57 times higher, while the odds of living in a cohabiting union instead of being married for working and middle class couples are, respectively, 1.34 and 1.27 times higher than the ones for upper class couples.

As expected, couples from the same religious denomination have lower odds of cohabiting than being married compared to couples from different religious denominations. However, it is interesting that couples who do not declare themselves as Catholic or Evangelical, and yet are from the same religious denomination, have higher odds of cohabiting than couples from different religious denominations. In comparison to being married, Evangelical couples present the lowest odds of forming unions out of wedlock (3.86 [1/0.26] times lower than couples without religion), followed by Catholics (1.48 [1/0.67] times lower than couples without religion). However, couples from other religious orientation have 1.11 times higher odds of cohabiting than couples from different religious denominations.

Turning to the control variables, the odds of consensual union relative to marriage decreases significantly when women's schooling increases. In comparison to women who attained a university education, the odds of cohabiting rather than being married for women with secondary education are 2.63 times higher and the odds for women with less than primary education is 3.36 times higher. Younger cohorts have much higher odds of cohabiting instead of being married in comparison to older ones. Considering that it is impossible to know if married couples have cohabited before getting married, this result can be related to the fact that younger cohorts are more likely to cohabit than older ones or that older cohorts turn consensual union into marriage with time ${ }^{6}$.

The control variable 'migrant' indicates that at least one of the spouses/partners was not born in the state of residence. Migrants have higher odds of cohabitating instead of being married than non-migrants. Then, other variables, as well as the remaining betweenstates variance on other variables in the model is not influenced by internal migration.

The majority of couples are from the lower social classes (74.5 percent), which may influence the results. In order to better understand the occurrence of consensual unions in different social classes in Brazil, it was examined whether the effect of children on the odds of consensual union in comparison to marriage differs from one class to another, by including an interaction term between the variables children and social class in model 2. However, different from the results found in an earlier unpublished version of this analysis that used census data from 2000 (COVRE-SUSSAI; MATTHIJS, 2010), the results of the interaction term were not significant.

\footnotetext{
${ }^{6}$ Theoretically, it could also mean that a person's second union is more likely to be permanent and formally institutionalized than when she or he was young, however there is little evidence of this in the literature.
} 
It is important to notice that, in a previous analysis using data from the census round of 2000 (COVRE-SUSSAI; MATTHIJS, 2010), the results of the interaction between number of children and social class were significant and showed that the likelihood of living in a consensual union instead of being married were very similar for childless couples from different social classes. However, for couples with children in 2000 , the probability of living in consensual unions instead of being married differs enormously between lower and higher social classes. While the presence of children increased the odds of lower social class couples to live in a consensual union, the same variable decreased the odds of couples from the higher social strata to be found in a consensual union. This change in the decade can be due to a fact described in a recent study published by Laplante and colleagues (2015). This study documented that recently higher educated Latin American women are having more children in consensual unions than they used to have before (LAPLANTE et al., 2015). Hence, the absence of significance in the interaction term can be another evidence of a possible change in the nuptial behavior of the upper social classes when living in consensual unions.

The question addressed in Model 3 is whether state variances are explained by the ethnic composition of the state, since cultural differences in Brazil are supposed to be related to different miscegenation processes throughout the country (RIBEIRO, 1997). It was found that consensual unions are less common in places with higher proportions of self-declared whites. Considering the decrease in the between-state variance from $\hat{\mathrm{u}}_{o j} 0.13$ to $\hat{\mathrm{u}}_{o j} 0.10$, it is possible to suggest that part of the between-state variance is explained by ethnic differences. This result needs to be interpreted carefully. Considering that the contextual variable 'whites' is included in the model without an individual level counterpart, the effect of this variable reflects both individual and contextual level effects. In this sense, the negative association between living in places with higher proportions of whites and living in consensual unions rather than in marriage reflect both the effect of living in a place with higher proportions of whites and the effect of being a white couple and of choosing to cohabit.

The study also checked out whether state variances were similarly or better explained by level of poverty, urbanization or socioeconomic development (HDI). The analysis also controlled for the state-level sex ratio. Considering that none of these effects were significant, these results were not included in Table 1.

\section{Conclusion}

This study investigated the socioeconomic features and the cultural context of consensual unions in Brazil. To this purpose, couples' level data stemming from the 2010 Brazilian census is used to analyze, inter alia, the extent to which couples' social classes, the presence of children and religious denomination are related to the odds of a couple living in a consensual union rather than being married. Considering the socioeconomic and 
cultural diversity found between Brazilian regions and their respective states, the influence of these specificities on nuptial behavior is also examined.

The results indicate that consensual unions in Brazil follow Latin American trends, inasmuch as they are more common among the lower social classes and educational groups. In these groups, consensual unions also present higher fertility. However, consensual unions are also found among the middle and upper social classes in the country, suggesting the coexistence of different types of consensual unions in Brazil.

In an earlier version of this analysis, which used census data from the 2000 Census, the results of the interaction term between the variable indicating the existence of children and the variable indicating the social class were significant. In that previous analysis, it was shown that childbearing in cohabitating unions is more common among the lower social strata than among the upper social classes. The chances of living in cohabiting unions for couples without children and from different social classes were very similar. However, children appeared to represent a disincentive for consensual unions among those in the upper classes, thus reducing the chances of consensual unions in this social group (COVRESUSSAI; MATTHIJS, 2010).

However, in the present analysis, based on 2010 census data, there are no significant differences in the chances of couples with or without children of living in consensual unions or being married. This result suggests that the social-class difference in the chances of living in cohabitating unions diminished between 2000 and 2010 in Brazil, at least with regards do fertility.

Religion was shown to continue to be a powerful mechanism of behavioral restriction. In line with the declared hypothesis, couples from different religious denominations have higher odds of being in a cohabiting union instead of being married. Couples with the same religious orientation, particularly Evangelicals, tend to cohabit less.

Cultural differences also influence the choice for consensual union instead of marriage in Brazil. States with higher proportions of self-declared whites have a lower incidence of consensual unions, meaning that the European model of marriage still plays a role in Brazilian nuptial behavior. Moreover, the between-states differences in terms of odds of consensual unions are inverted when controlling for the proportion of whites and other couples' level variables in the model. Considering that contextual variables, such as sex ratio, level of poverty, urbanization and HDI, were considered as non-significant, it can be suggested that the remaining states-level variance is due to additional cultural differences.

This study contributes to the research on demography and family sociology in Brazil and Latin America by depicting the influence of socioeconomic factors on consensual unions in different social strata, as well as by modeling the effect of diverse Brazilian cultures on nuptial behavior. Based on this, it is possible to attest that nuptial behavior varies not only between states, but also between different social classes within each state.

Demographic Census data have the advantage of covering the whole country, however their use implies several limitations. The cross-sectional design does not allow the verification 
of changes in couples' life. For instance, it is not possible to know if the older cohorts had cohabited before getting married and, consequently, if the younger ones are likely to get married in the future. In addition, the particularities of each family are omitted. In this sense, the need to collect more detailed, longitudinal and nationally representative data is evident.

This research has raised many questions in need of further investigation regarding consensual unions in Brazil and in Latin America. Additional work can be done to examine the social forces related to the choice of, or the transition to, marriage or consensual unions in different Latin American countries.

\section{References}

ALMEIDA, A. M. Notas sobre a família no Brasil. In: ALMEIDA, A. M. de (Ed.). Pensando a família no Brasil: da colônia à modernidade. Rio de Janeiro: Espaço e Tempo, 1987.

ALVES, J. E. D. Brasil e a diversidade religiosa: evangélicos passam católicos na baixada fluminense. Ecodebate: Cidadania e Meio Ambiente, 2012. Available at: 〈http://www.ecodebate. com.br/2012/07/06/brasil-e-a-diversidade-religiosa-evangelicos-passam-catolicos-na-baixadafluminense-artigo-de-jose-eustaquio-diniz-alves> Access: 15 May 2013.

ARRIAGADA, I. Changes and inequality in Latin American families. Cepal Review, n. 77, p. 135-153, 2012.

$B C B$. Evolução do IDH das grandes regiões e unidades da federação. Boletim Regional do Banco Central do Brasil, p. 91-94, janeiro 2009. Available at: 〈http://www.bcb.gov.br/pec/ boletimregional/port/2009/01/br200901b1p.pdf> Access: 10 Mar. 2013.

BROWN, S. L. Union transitions among cohabitors: the significance of relationship assessments and expectations. Journal of Marriage and Family, v. 62, n. 3, p. 833-846, 2000.

CAMARANO, A. A.; CARNEIRO, I. G. Padrões de formação de família por regiões brasileiras e grupos sociais: diferenças ou semelhanças. In: XI ENCONTRO NACIONAL DE ESTUDOS POPULACIONAIS. Anais... Caxambu, MG: Abep - Associação Brasileira de Estudos Populacionais, 1998. p. 31-50. Available at: 〈http://www.abep.nepo.unicamp.br/docs/anais/PDF/1998/a123.pdf〉 Access: 5 Apr. 2010.

CASTRO-MARTIN, T. Consensual unions in Latin America: Persistence of a dual nuptiality system. Journal of Comparative Family Studies, v. 33, n. 1, p. 35-55, 2002.

CORRÊA, M. Repensando a família patriarcal brasileira: notas para o estudo das formas de organização familiar no Brasil. In: CORRÊA, M. (Ed.). Colcha de retalhos: estudos sobre a família no Brasil. Campinas: Editora da Unicamp, 1993.

COVRE-SUSSAI, M.; MEULEMAN, B.; BOTTERMAN, S.; MATTHIJS, K. Traditional and modern cohabitation in Latin America: a comparative typology. Demographic Research, v. 32, p. 873-914, 2015.

COVRE-SUSSAI, M. Cohabitation and human development in Latin America and developed countries. International Journal of Sociology of the Family, v. 40, n. 2, p. 153-173, 2014.

COVRE-SUSSAI, M.; MEULEMAN, B.; VAN BAVEL, J.; MATTHIJS, K. Measuring gender equality in family decision making in Latin America: a key towards understanding changing family configurations. Genus, v. 69, n. 3, p. 47-73, 2013.

COVRE-SUSSAI, M.; MATTHIJS, K. Socio-economic and cultural correlates of cohabitation in Brazil. In: CHAIRE QUÉTELET CONFERENCE. Louvain-la-Neuve, Belgium, 2010. 
DE VOS, S. Latin American households in comparative perspective. Population Studies, v. 41, n. 3, p. 501-517, 1987.

Nuptiality in Latin America: the view of a sociologist and family demographer. Madison, Wisconsin: Center for Demography and Ecology, University of Wisconsin-Madison, 1998.

DUNCAN, C.; JONES, K.; MOON, G. Context, composition and heterogeneity: using multilevel models in health research. Social Science; Medicine, v. 46, n. 1, p. 97-117, 1998.

ESTEVE, A.; LESTHAEGHE, R.; LOPEZ-COLAS, J.; LOPEZ-GAY, A.; COVRE-SUSSAI, M. Cohabitation in Brazil, 1970-2010. Historical legacy and recent evolution. Barcelona: Unpublished Manuscript, Centre d’Estudis Demogràfics, 2013.

ESTEVE, A.; LESTHAEGHE, R.; LÓPEZ-GAY, A. The Latin American cohabitation boom, 1970-2007. Population and Development Review, v. 38, n. 1, p. 55-81, 2012.

FREYRE, G. Casa grande e senzala: formação da família brasileira sob o regime de economia patriarcal. 41. ed. Rio de Janeiro: Record, 2000.

GREENE, M. E.; RAO, V. The marriage squeeze and the rise in informal marriage in Brazil. Biodemography and Social Biology, v. 42, n. 1-2, p. 65-82, 1995.

GUIMARÃES NETO, L. Ciclos econômicos e desigualdades regionais no Brasil. Cadernos de Estudos Sociais, v. 14, n. 2, p. 315-342, 1998.

HOLT, K. Marriage choices in a plantation society: Bahia, Brazil. International Review of Social History, v. 50, supl. 13, p. 25-41, 2005.

IBGE. Censo Demográfico 2010: nupcialidade, fecundidade e migração. Rio de Janeiro, 2010.

. Síntese dos indicadores sociais: uma análise das condições de vida da população brasileira. Rio de Janeiro, 2012. ibge.gov.br/s.

. Censo Demográfico. Retrieved March 10, 2013a. Available at: «http://www.sidra.

Estatísticas do Registro Civil. Retrieved March 15, 2013b. Available at: 〈http://www. sidra.ibge.gov.br/>.

IPEA. Dimensão, evolução e projeção da pobreza por região e por estado no Brasil. Comunicado do Ipea, n. 58, 2010.

JELIN, E. Las familias latinoamericanas en el marco de las transformaciones globales. In: ARRIAGADA, I. (Ed.). Familias y políticas públicas en América Latina: una historia de desencuentros. Santiago de Chile: ECLAC, United Nations, 2007. p. 93-121.

LAPLANTE, B.; CASTRO-MARTÍN, T.; CORTINA, C.; MARTÍN-GARCÍA, T. Childbearing within marriage and consensual union in Latin America, 1980-2010. Population and Development Review, v. 41, n. 1, p. 85-108, 2015.

LAPLANTE, B.; STREET, C. Los tipos de unión consensual en Argentina entre 1995 y 2003: una aproximación biográfica. Estudios Demográficos y Urbanos, v. 24, n. 2, p. 351-387, 2009.

LAZO, A. C. G. V. Marital fertility in Brazil: differential by type of union and its importance in the fertility transition, 1976-1995. Brazilian Journal of Population Studies, n. 2, p. 55-67, 1999.

LAZO, A. C. G. V.; MORAES, J. R. As uniões consensuais no Estado do Rio de Janeiro em 2000: um estudo utilizando regressão logística. In:XIV ENCONTRO NACIONAL DE ESTUDOS POPULACIONAIS. Anais... Caxambu, MG: ABEP - Associação Brasileira de Estudos Populacionais, 2004. p. 1-22. Available at:〈http://www.abep.nepo.unicamp.br/site_eventos_abep/PDF/ABEP2004_243.pdf〉 Access: 10 Apr. 2010. 
LESTHAEGHE, R. The unfolding story of the second demographic transition. Population and Development Review, v. 36, n.2, p. 211-51, 2010.

LESTHAEGHE, R.; SURKYN, J. Cultural dynamics and economic theories of fertility change. Population and Development Review, v. 14, n. 1, p. 1-45, 1988.

MARCONDES, G. La normalización jurídica de la familia, vida conyugal y reproducción en Brasil. In: BINSTOCK, G.; MELO VIEIRA, J. (Ed.). Nupcialidad y familia en la América Latina actual. Rio de Janeiro: Alap, 2011. p. 255-280.

MINNESOTA POPULATION CENTER. Integrated public use microdata series, international: version 6.1 [Machine-readable database]. Minneapolis: University of Minnesota, 2011.

NERI, M. C. A nova classe média. Rio de Janeiro: FGV/Ibre, CPS, 2008.

PARRADO, E.; TIENDA, M. Women's roles and family formation in Venezuela: new forms of consensual unions? Biodemography and Social Biology, v. 44, n. 1, p. 1-24, 1997.

PNUD. Atlas do desenvolvimento humano. 2010.

POTTER, J. E.; SCHMERTMANN, C. P.; ASSUNÇÃO, R. M.; CAVENAGHI, S. M. Mapping the timing, pace, and scale of the fertility transition in Brazil. Population and Development Review, v. 36, n. 2, p. 283-307, 2010.

RIBEIRO, D. 0 povo brasileiro: a formação e sentido do Brasil. São Paulo: Companhia das Letras, 1997.

SAMARA, E. de M. Tendências atuais da história da família no Brasil. In: ALMEIDA, A. M. de (Ed.). Pensando a família no Brasil: da colônia à modernidade. Rio de Janeiro: Espaço e Tempo, 1987.

A família no Brasil: história e historiografia. História Revista, v. 2, n. 2, p. 7-21, 2010.

SAMARA, E. de. M.; COSTA, D. I. P. Family, patriarchalism, and social change in Brazil. Latin American Research Review, v. 32, n. 1, p. 212-225, 1997.

SOUZA, C. V. E.; BOTELHO, T. R. Modelos nacionais e regionais de família no pensamento social brasileiro. Estudos Feministas, n. 2, p. 414-432, 2001.

VIGNOLI-RODRÍGUEZ, J. Unión y cohabitación en América Latina: ¿modernidad, exclusión, diversidad? Santiago de Chile: ECLAC, United Nations, 2005.

\section{About the author}

Maira Covre-Sussai is PhD in Social Sciences (University of Leuven - KU Leuven), professor at Rio de Janeiro State University and coordinates the Center for Studies on Contemporary Inequalities and Gender Relations - Nuderg.

\section{Contact address}

Maira Covre-Sussai

Rua São Francisco Xavier, 524, sala 9034 bloco A, Maracanã

20250-013 - Rio de Janeiro-RJ, Brazil 


\section{Resumo}

Características socioeconômicas e culturais das uniões consensuais no Brasil

A prática de uniões consensuais entre as camadas sociais de baixa renda é bem conhecida na América Latina. No entanto, a incidência deste tipo de união está aumentando na região entre os grupos mais educados e em países onde nunca foi predominante, como no Brasil. Este estudo utiliza dados sobre casais do censo demográfico brasileiro (2010), disponibilizado pelo IPUMS ( $N=193.689)$ para identificar as características socioeconômicas e culturais das uniões consensuais no Brasil. 0 efeito da educação da mulher, classe social do casal, filhos e religião é apresentado. Utilizando uma análise multinível, o ambiente cultural em que estas uniões ocorrem é investigado. Os resultados indicam que fatores socioeconômicos diferenciam as uniões consensuais no Brasil. Uniões estáveis são mais comuns entre as classes sociais mais baixas e mulheres com menor grau de escolaridade, mas também encontradas entre as classes superiores. A diversidade cultural existente entre os estados brasileiros também é refletida no comportamento conjugal. Embora tenha sido encontrada uma variação significativa ao nível do estado, a composição étnica de cada estado explica parcialmente estas diferenças.

Palavras-chave: Uniões consensuais. Diferenças culturais. Renda do casal. Religião. Filhos. Análise multinível.

\section{Resumen}

\section{Características socioeconómicas y culturales de las uniones consensuales en Brasil}

La convivencia conyugal entre los estratos sociales más bajos es una práctica muy conocida en América Latina. Sin embargo, estas uniones de convivencia están aumentando en la región entre los grupos con un nivel alto de educación formal y en países donde nunca fue sobresaliente, como en Brasil. Esta investigación utiliza datos de las parejas de los censos demográficos proporcionados por IPUMS ( $\mathrm{N}=193.689)$ para identificar las características socio-económicas y culturales de la unión consensual en Brasil. El efecto de la educación de la mujer, la clase social de la pareja, los hijos y la religión son analizadas. Utilizando un análisis multinivel, se pone atención especial al ambiente cultural donde ocurren estas uniones. Los resultados indican que los factores socio-económicos afectan las uniones consensuales en Brasil. Esas uniones siguen siendo más comunes entre las clases sociales más bajas y las mujeres que poseen menos educación formal, sin embargo también se encuentran entre las clases altas. La diversidad cultural encontrada entre los estados brasileños también se refleja en el comportamiento conyugal. Mientras que se halla diferencia significativa al nivel del Estado, la composición étnica de cada estado explica parcialmente estas diferencias.

Palabras clave: Uniones consensuales. Diferencias culturales. Ingresos de la pareja. Religión. Hijos. Análisis multinivel.

Recebido para publicação em 25/09/2015

Recomendado para publicação em 19/03/2016

Aceito para publicação em 09/04/2016 